\title{
Epidemiologic Profile of Brachial Plexus Traumatic Lesions in Adults at an Outpatient Clinic in Minas Gerais
}

\section{Perfil epidemiológico das lesões traumáticas do plexo braquial em adultos atendidos em ambulatório de referência em Minas Gerais}

\author{
Célia Maria Oliveira ${ }^{1}$ José Augusto Malheiros ${ }^{1}$ Leonardo de Andrade Moreira ${ }^{1}$ \\ Luiz Alberto Otoni Garcia ${ }^{1}$ Thiago Oliveira Lemos Lima ${ }^{1}$ Selme Siqueira de Matos ${ }^{1}$ Luiz Cláudio Ribeiro ${ }^{1}$ \\ ${ }^{1}$ Department of Neurosurgery, Hospital das Clínicas da Universidade \\ Federal de Minas Gerais, Belo Horizonte, MG, Brazil \\ Arq Bras Neurocir 2016;35:193-196. \\ Address for correspondence José Augusto Malheiros, PhD, \\ Department of Neurosurgery, Hospital das Clínicas da Universidade \\ Federal de Minas Gerais, Alameda Alfredo Balena, 110, Belo Horizonte, \\ MG, Brazil, CEP: 30.130-100 (e-mail: zeugusto@globo.com).
}

\section{Abstract \\ Keywords \\ - brachial plexus \\ - injury \\ - epidemiology \\ - repair time}

\section{Resumo}

Palavras-chave

- plexo braquial

- trauma

- epidemiologia

- tempo de reparo
This study aimed to raise demographic and epidemiological aspects as well as the time until surgery in patients with brachial plexus injury in Minas Gerais, Brazil. Forty-seven patients who underwent surgery were evaluated retrospectively in the period 2010 to 2011. The majority (91.5\%) were male, mean age 34.4 years; $56.5 \%$ were single or separated; $55.3 \%$, from the countryside of Minas Gerais. With regard to schooling, $47.8 \%$ had not completed elementary school level. Most of them (43.5\%) had a heavy duty job, including houseworking, agriculture, industry. Traffic accidents were the main cause of the injury (97.9\%); and motorcycle accidents accounted for $68.1 \%$ of the lesions. The time between the accident and the first view by brachial plexus specialist ranged from 1 month to 30 months. The time between query and specialized surgical treatment ranged from 5 to 18 months, mean 10 months. This study points out the epidemiological characteristics of patients with brachial plexus injuries in Minas Gerais, Brazil. Most of the injuries occurred after motorcycle accident in male patients with unfavorable social and economic conditions. In addition, the surgical timing was far above the recommended, resulting in an unfavorable prognosis for functional recovery.

O presente estudo objetivou levantar aspectos sociodemográficos e epidemiológicos, bem como o intervalo de tempo até a cirurgia, dos pacientes com trauma do plexo braquial em Belo Horizonte (MG). Quarenta e sete pacientes submetidos à cirurgia foram avaliados retrospectivamente no período de 2010 a 2011 . A maioria $(91,5 \%)$ era do sexo masculino, com média de idade de 34,4 anos; $56,5 \%$ eram solteiros ou separados; $55,3 \%$, provenientes do interior do estado de Minas Gerais. No que se refere ao nível de escolaridade, $47,8 \%$ não haviam completado o nível de ensino fundamental. A maioria deles $(43,5 \%)$ exercia atividade braçal (serviços gerais, agricultura, indústria e received

November 15, 2015 accepted

December 27, 2015

published online

August 24, 2016
DOI http://dx.doi.org/ 10.1055/s-0036-1581082. ISSN 0103-5355.
Copyright $@ 2016$ by Thieme Publicações License terms

Ltda, Rio de Janeiro, Brazil 
construção civil). Os acidentes de trânsito foram os principais causadores de trauma (97,9\%), sendo os acidentes de motocicleta responsáveis por $68,1 \%$ das lesões. 0 tempo entre o acidente e o atendimento pelo médico especialista variou de 1 mês a 30 meses. $\mathrm{O}$ tempo entre a consulta especializada e o tratamento cirúrgico variou de 5 a 18 meses com média de 10 meses. O presente estudo aponta as características epidemiológicas dos pacientes com lesões de plexo braquial em Minas Gerais. A maior parte das lesões ocorreu após acidente de moto, em pacientes do sexo masculino, com condições sociais e econômicas desfavoráveis. Além disso, o tempo até o reparo das lesões foi bem acima do preconizado, implicando em prognóstico desfavorável para recuperação funcional.

\section{Introduction}

The brachial plexus is a complex nerve structure formed by the $\mathrm{C} 5, \mathrm{C} 6, \mathrm{C} 7, \mathrm{C} 8$, and $\mathrm{T} 1$ roots and may also receive contributions from $\mathrm{C} 4$ and $\mathrm{T} 2$. Its peculiar anatomical arrangement, emerging from the spine and passing through mobile portions of the neck, thoracic outlet, shoulder, and upper limb makes it vulnerable to sprains in cases of traffic accidents. ${ }^{1,2}$

In Brazil, the incidence of brachial plexus injury is not clear and the health system is inefficient for its treatment or referral in a timely manner. ${ }^{2}$

The purpose of this study was to analyze the demographic and epidemiological aspects of brachial plexus trauma in patients treated in the outpatient services of two large hospitals in Belo Horizonte, Minas Gerais.

\section{Patients and Methods}

A cross-sectional study was conducted in adult patients who had a diagnosis of brachial plexus injury treated at the outpatient services of two large hospitals in Belo Horizonte, Minas Gerais, from 2010 to 2011.

Information was obtained on sociodemographic aspects such as age, sex, education, marital status, number of children, place of residence, profession/occupation, and religion. Epidemiological aspects were observed as was the cause of trauma, mechanism of trauma, pain, therapeutic treatment, and duration of treatment.

The study included patients with brachial plexopathy due to trauma, aged 18 years or older, and who provided informed consent.

Data was collected through structured interviews. Clinical assessment, magnetic resonance imaging and electromyography were used for diagnosing brachial plexus injury.

This study was approved by all of the involved institutions (Ethics and Research Committee of the Hospital Felício Rocho, Opinion No. ETIC 332/10; Ethics and Research Committee of the Federal University of Minas Gerais (UFMG), Opinion No. ETIC 22/10; and Education, Research and Extension Department of the Hospital das Clínicas [DEPE] UFMG).

The collected data were included in an Excel spreadsheet and analyzed using R software, version 2.15.0, and are presented by average and standard deviation for numerical variables and ratios for categorical variables.

\section{Results}

The population of the study consisted of 47 patients. Most of them (91.5\%) were men with an average age of 34.4 years (ranging from 18 to 70 years); $51 \%$ of the patients were aged $<29$ years, and $57.4 \%$ (27 patients) were single and childless or divorced.

Twenty-six patients (55.3\%) were from the rural parts of the state of Minas Gerais and the remaining ones were from the metropolitan region of Belo Horizonte.

Twenty-three patients (48.9\%) had not completed elementary school. Of the remaining patients, 13 (27.6\%) had completed elementary school and $11(23.5 \%)$ had completed the intermediate level education.

The work activities of these patients were the most varied. Twenty of them (42.5\%) worked in manual labor (general services, agriculture, industry, and construction), 17 patients (36.1\%) were self-employed and 3 patients (6.3\%) were retired. The remaining 7 patients (15.1\%) worked on several activities, with one patient performing each activity (-Fig. 1).

The main causes of the brachial plexus injury were motorcycle accidents (32 patients, 68.1\%), followed by cycling accidents ( 5 patients, $10.6 \%$ ), falls ( 4 patients, $8.5 \%$ ) and accidents involving firearms (2 patients, $4.3 \%$ ). Vehicle

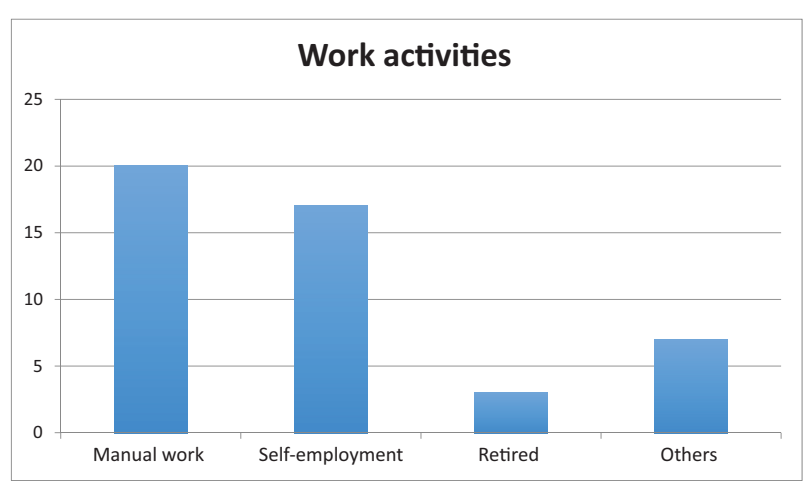

Fig. 1 Work activities of patients with brachial plexus injury. 
accidents (tractors, cars, being run over) were the cause of trauma for 3 patients (6.3\%), and for 1 patient (2.1\%), the injury was surgery-related (-Fig. 2 ).

The time between the occurrence of the injury and the moment it was treated by a specialist ranged from 1 month to 30 months. The time between the first medical appointment and the surgical treatment ranged from 5 to 18 months with an average of 10 months.

\section{Discussion}

In the study, $91.5 \%$ of patients were men, and $51 \%$ were aged between 18 and 29 years. These data are consistent with the existing literature on trauma, generally showing a higher incidence in young men.,

In regards to the causes of brachial plexopathy, this study is in accordance with the national and international studies, in which main cause was accidents related. ${ }^{1,5,6}$ Accidents with two-wheeler vehicles (motorcycles and bicycles) accounted for $78.7 \%$, and other vehicles for $2.1 \%$ of the cases.

Falls were also a cause of brachial plexopathy, including simply falling down and falling from a tractor. This shows that although most injuries are associated with high-impact accidents, it is also possible that a low-impact accident may cause brachial plexus.

Another characteristic revealed by this study was the predominance of people who had not completed elementary school. In general, their professions/occupations were related to a low level of education, with manual activities prevailing, such as general services and those related to working in the field.

Because they generally harm the upper limbs, brachial plexus injuries cause limitations that may be mild or severe, with significant socioeconomic impact and high cost to the health system. ${ }^{1,2}$

As regards their origin, over $50 \%$ of the patients lived in the state of Minas Gerais. This finding indicates the difficulty of articulation and implementation of comprehensive care by the networks of the Unified Health System in medium and small cities of the State, generating an overpresence of specialist services in large cities, as in the case of patients with brachial plexopathy.

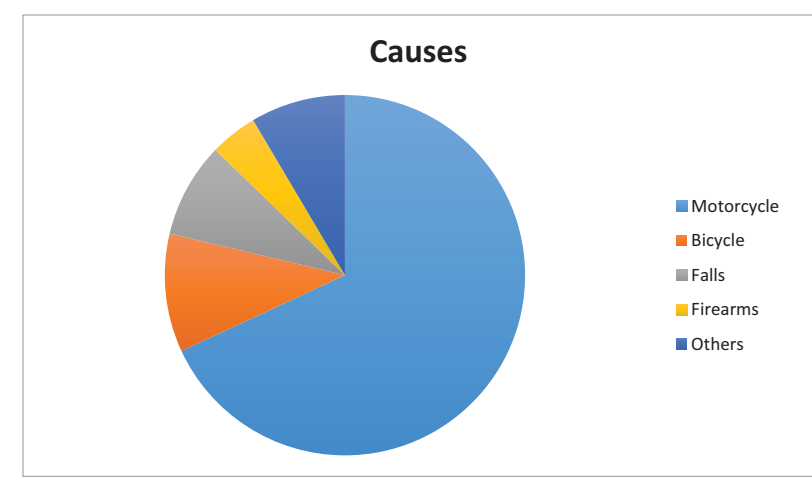

Fig. 2 Causes of the brachial plexus injury.
In this study, the time between the occurrence of the injury and care provided by a specialist ranged from 1 month to 30 months, which shows the absence of a pattern and the variation of time elapsed until the assessment by an specialist.

Obtaining the best results in the treatment of brachial plexus injuries directly depends on an early forwarding of the patients to major centers, in addition to early surgical treatment of the selected cases. ${ }^{1,8}$

Traumatic injuries of peripheral nerves may be classified as open and closed, depending on the skin's integrity. The closed ones are most commonly associated with nerve's disruption and the occurrence of neuropraxia and axonotmesis as predominant mechanisms. ${ }^{8-10}$ The main injury that affects the brachial plexus is a closed injury. In these cases, when spontaneous recovery is possible, surgery is indicated only after 3 months. This period is arbitrarily based on axonal growth (1-3 mm/day) and electromyography evaluations. $8,9,11$

On the contrary, the occurrence of a penetrating open injury of the brachial plexus requires an early treatment. ${ }^{8}$ Avulsion injuries should be treated early (before 3 months) to optimize surgical outcomes. Non-avulsion injuries should be followed up until 6 months after the trauma. As a general rule, in the absence of spontaneous recovery, a surgical procedure is recommended and should not be delayed for more than 9 months between trauma and surgery. $8,9,11$

The neurological recovery of patients with brachial plexopathy, therefore, is related to the promptness in starting the specialized treatment, which is based on a reference and counter-reference model. We noted that such a reference model is lacking. There are delays in both the reference and the authorization of the surgery by the Unified Health System. First, the patient must get to the specialist. When the need for surgery is confirmed, the patient must still wait for the authorization of the procedure and a free place on the waiting list.

The time between the first medical appointment and the surgical treatment ranged from 5 to 18 months (10 months in average), well above the ideal time recommended in the literature. ${ }^{8,9,11}$ The time between the occurrence of the injury and the beginning of the treatment was, therefore, long. This situation may be related to the fact that the referral of users from the public health system to a specialized service, is bureaucratic, resulting from traditional reference and counter-reference systems based on the logic of fragmented care. ${ }^{4}$ Also the severity of the clinical picture, which requires strict attention, contributes to delay in the implementation of specialized care.

Care for patients with brachial plexus injury is fragmented, with an overload of the specialized services in major centers. Planning for the assistance of a victim of brachial plexus trauma and defining prevention strategies for this type of event are necessary actions at a local, state, and national level.

\section{Conclusion}

This study presents the epidemiological characteristics of patients with brachial plexus injuries in Minas Gerais. Most 
of the injuries occurred after a motorcycle accident, in male patients with unfavorable social and economic conditions. In addition, the time elapsed until the treatment of the injuries was well above the recommended values, resulting in an unfavorable prognosis for functional recovery.

\section{References}

1 Dubuisson AS, Kline DG. Brachial plexus injury: a survey of 100 consecutive cases from a single service. Neurosurgery 2002; 51(3):673-682, discussion 682-683

2 Flores LP. Epidemiological study of the traumatic brachial plexus injuries in adults. Arq Neuropsiquiatr 2006;64(1):88-94

3 World Health Organization. Global status report on road safety 2013: supporting a decade of action. Switzerland: WHO; 2013

4 Reichenheim ME, de Souza ER, Moraes CL, et al. Violência e Lesões no Brasil: efeitos, avanços alcançados e desafios futuros. Saúde no Brasil 2011;5:75-89
5 Cardona D, Peláez E, Aidar T, Ribotta B, Alvarez MF. Mortalidade por causas externas em três cidades latino-americanas: Córdoba (Argentina), Campinas (Brasil) e Medellín (Colômbia), 19802005. Rev Bras Estud Popul 2008;25(2):335-352

6 Krug EG. Injury surveillance is key to preventing injuries. Lancet 2004;364(9445):1563-1566

7 Caixeta CR, Minamisava R, Oliveira LMAC, Brasil VV. Traffic injuries among youth in Goiânia, Goiás State. Cien Saude Colet 2010;15(4):2075-2084

8 Spinner RJ, Kline DG. Surgery for peripheral nerve and brachial plexus injuries or other nerve lesions. Muscle Nerve 2000;23(5): 680-695

9 Weber RV, Mackinnon SE. Bridging the neural gap. Clin Plast Surg 2005;32(4):605-616, viii

10 Hall S. Nerve repair: a neurobiologist's view. J Hand Surg [Br] 2001;26(2):129-136

11 Martins RS, Bastos D, Siqueira MG, Heise CO, Teixeira MJ. Traumatic injuries of peripheral nerves: a review with emphasis on surgical indication. Arq Neuropsiquiatr 2013;71(10): 811-814 